\title{
The Use of Positive and Negative Politeness Strategies to Express Request in English and Armenian Cultures
}

\author{
Marine Yaghubyan \\ Yerevan State University
}

\begin{abstract}
Politeness is an indispensable topic in pragmatics. The standard of politeness may vary from group to group, from situation to situation and even from person to person. In pragmatics the principle of politeness is related to the choices that are made in the language usage, the linguistic expressions that give people space and express a friendly attitude.

The present article focuses on the examination and comparison of positive and negative politeness strategies to express request in English and Armenian cultures. The analysis shows that in Armenian culture positive politeness is highlighted. On the contrary, in English culture requests are made within negative politeness strategies.
\end{abstract}

Key words: positive politeness, negative politeness, request, culture, positive face, negative face, politeness strategies.

\section{Introduction}

Politeness is a culturally defined theory. It is possible to treat politeness as a fixed concept, as in the idea of polite social behavior, or etiquette within a culture. It includes being tactful, generous, modest, and sympathetic towards each other (Yule 1996:60). That is to say, what is viewed polite in one culture can sometimes be rude, indecent and inappropriate in another cultural context.

It should be stated that all interlocutors are interested in keeping two types of faces while communicating with each other. So every interlocutor possesses both positive and negative faces. Negative face is defined by G. Yule as the need to be independent, and positive face is the need to be connected. It is the main 
claim to territories, maintenance of privacy, and rights to non-distraction. Meanwhile positive face can be characterized by positive desires to be liked and regarded with respect (Yule 1996:62).

In this article we aim at examining the differences in the ways of expressing request in English and Armenian cultures, while paying much attention to positive and negative politeness strategies.

\section{Positive Politeness}

Positive politeness indicates not only similarities among the interlocutors but also it expresses appreciation of the interlocutor's self-image. As can be observed, we often make use of positive politeness strategy in order to avoid conflicts, to make the hearers feel good about themselves by taking into consideration their desires, needs, wants or interests. It is important to mention that positive politeness strategy is mainly used in situations where speakers and hearers know each other well enough. The tendency to use positive politeness forms, emphasizing closeness between speaker and hearer, can be seen as solidarity strategy. Linguistically, such a strategy will include personal information, use of nicknames, sometimes even abusive terms, particularly among males, and shared dialect or slang expressions (Yule 1996: 64-65). This can be explained by the illustration provided below:

\section{"Hey ducky, can you give me that cup?"}

(Galsworthy 1976:15)

According to the above-mentioned example, the speaker needs some cup and wants to get it from the hearer, who is presumably his friend, since he calls him by a nickname "ducky" to identify his "friend", which normally cannot be used with a stranger or an acquaintance to sound in a proper way. It should be mentioned that there might be the risk of confrontation, misunderstanding, and rejection in this case. By the way, speakers do not run the risk of confrontation by utilizing this kind of nicknames in the group of their friends since nicknames show solidarity. Then, we should note that another factor, which should be taken into consideration in this particular situation, is the proper use 
of correct intonation since it has an ultimate power to cause misunderstandings between the interlocutors. Frequently, a solidarity strategy will be marked via inclusive terms such as "we" and "let's" (Yule 1996:65). This can be shown by the following example:

Let's have a glim' said Sikes, 'or we shall go breaking our necks, or treading on the dog.

(Dickens 1945:396)

It is worth noting that we can make use of positive politeness strategy, in order to offer the hearer something, or give promises as shown by the following example:

Stand still a moment, and I'll get you one.

(Dickens 1945:396)

\section{Negative Politeness}

Negative politeness is the need to be autonomous and free from imposition. The tendency to use negative politeness forms emphasizing the hearer's right to freedom, can be seen as a deference strategy. It can be the typical strategy of a whole group or just an option used on a particular occasion. The language associated with a deference strategy emphasizes the speaker's and the hearer's independence, marked via an absence of personal claims (Yule 1996:66).

It is worth mentioning that the usage of negative politeness strategies presumes a direct connection between indirectness and politeness. Admittedly, in order to show negative politeness, the speaker should be indirect.

"Would he have minded you're going?"

(Galsworthy 1976:163)

As can be observed, we utilize questions and hedges in order to show negative politeness:

Could you possibly invite her to lunch tomorrow?

(Fitzgerald 1941:120) 


\section{Cross-Cultural Comparison}

It is worth noting that historically independence and freedom in actions have always been crucial values in Armenian culture. Nevertheless, it is safe to say that Armenian culture is a collectivistic one, hence Armenians attach too much importance to the needs and goals of the group (Triandis 2001). They emphasize a group as one unity and relationships within the members of a group play a great role in forming each individual's personality. In Armenian culture families and communities have an indispensable role and people are likely to do what is best for society. In Armenian society people are regarded as good if they are kind, generous, helpful, dependable and mostly take into consideration the needs and desires of others. This leads to the conclusion, that Armenians tend to show less social distance, which means that people interact with one another directly. Furthermore, taking into account the abovementioned characteristic features of Armenian culture, we can state positive politeness strategies are mainly utilized and accepted by Armenian society.

As can be observed, Armenians tend to show positive face since each representative of Armenian culture has the need to be accepted and sometimes even liked by others. As a part of a collectivistic culture, Armenians like to be treated as members of the same group and know that their needs and desires can be shared by others. They try to avoid conflicts and make the hearers feel good about themselves, paying much attention to their desires, needs, and interests, hence it can be claimed that positive politeness is highlighted in Armenian culture.

Conversely, in English culture people value individuality and independence, therefore it is a vivid illustration of an individualistic culture. As is stated, individualistic cultures focus on characteristics like independence and assertiveness. They value a person's freedom to act and appreciate personal identity. Thus, in English culture, negative politeness is more stressed and people tend to show negative face, indicating the need to be independent, to keep privacy and have right to non-distraction. In brief, in English culture requests are made within negative politeness strategies. 
As can be observed in Armenian culture, the usage of interrogative forms beyond the area of questions is truly bounded. The interrogative form is not valued in the cultural perspective to perform directives, hence there was no cultural need to evolve special interrogative tools for accomplishing speech acts apart from questions and more specifically for carrying out directives such as the usage of "Won't you?" This idea can be illustrated by the following sentences:

Won't you join us? They will be delighted, everyone of them.

(Dickens 1945:658)

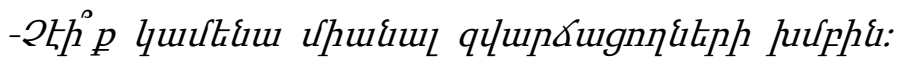

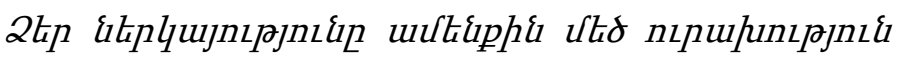
quiunduinten:

(Dickens 1988:456)

Nevertheless, if there is a possibility of having a context-free, general interpretation of the conversation provided above, then we will presumably hear or read a polite request which is being expressed, and a positive or a negative action will pursue.

In Armenian the avoidance of imperative and the usage of interrogative devices are not connected with the principle of politeness, as it is in English. By the way, there is an obvious similarity related to the expression "would you mind" which is utilized both in Armenian and in English in order to make a polite request:

Would you mind coming presently?

(Galsworthy 1932:290)

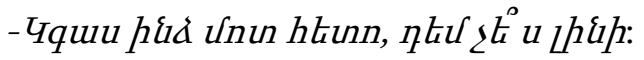

(Galsworthy 1975:707)

Nevertheless, it can be indicated that the usage of the interrogative forms in requests is hardly ever expressed in Armenian. Generally speaking, there 
might be a slight possibility, but compared to English, the possibilities are truly bounded. Hence, one could express requests, or speech acts closely referring to requests, by apparently asking about the addressee's aptitude to act, or about his or her decency or kindness.

Could you tell me if there are likely to be any more of you coming down?

(Galsworthy 1932:467)

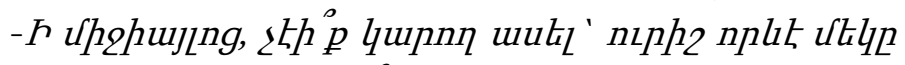
àtpnighg uhinp nuli oujuutin quinz:

(Galsworthy 1975:196)

As can be noted, the polite interrogative request form "Yupnn $\mathrm{th}^{\circ} \mathrm{p}$ ", which equals to the English form "Could you?", is not commonly utilized in Armenian culture. Instead, Armenians more frequently make use of the form

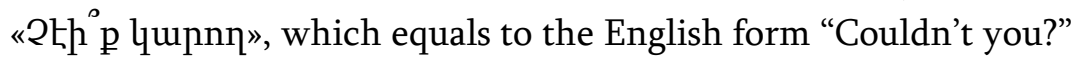

Couldn't you hear the noise?

(Dickens 1945:370)

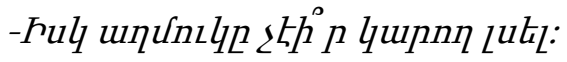

(Dickens 1988:358)

Compared to English, in the Armenian language requests are often interpreted in the imperative form. It is worth mentioning that the teachers are the ones who excessively express requests in imperative forms during their lessons in the classroom as in "Open your copy-books, write the date!" and in Armenian, the same sentence will be as «fugtip untunptip l qpip ưuuphц». Let us bring some other examples, which illustrate the usage of request in imperative form:

1. "Bow to the board," said Bumble.

(Dickens 1945:34)

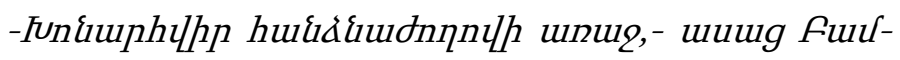
FLLL:

(Dickens 1988:248) 
2. "Come!" said Gamfield; say four pound, gen'lmen say four pound, and you have got rid of him for good and all. There!

(Dickens 1945:62)

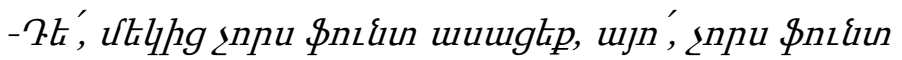

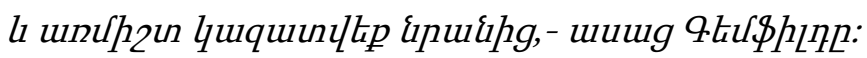

(Dickens 1988:257)

It can be stated that both in English and Armenian, requests are made with the forms "Yupt $\mathrm{h}^{\circ} \mathrm{k}$ " and "May I?" in order to express polite requests in various situations:

1. "May I accompany you?" said the book stall-keeper, looking in.

(Dickens 1945:268)

- Elipu kuujtilny:

(Dickens 1988:325)

2. May I ask the name of the gentleman, who has given us that striking piece of information?

(Galsworthy 1932:499)

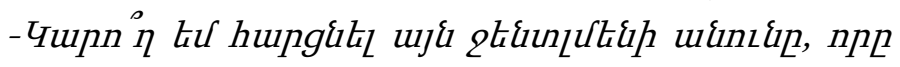

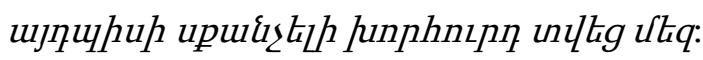

(Galsworthy 1975:210)

However, it must be noted that one could not use literal Armenian equivalents of the phrases "Would you do it?", "Won't you do it", “Why don't you do it" or "Would you like to do it?" in order to express requests and ask people to do something.

It is important to mention that pseudo-questions, such as "Would you like to?" or "Do you want to", are actually defined as requests, apparently inquiring about the addressee's wants. These questions appear to be odd and amusing from the point of view of Armenian culture. Nevertheless, not only the variety 
of reasonable interrogative devices, distinguishing Armenian directives from the English ones are striking, but also the differences in function should be taken into consideration. Hence, interrogative directives sound orderly and elaborately polite in Armenian. As can be mentioned, in this perspective the imperative is impartial, which neither prevents nor invites a verbal response. Beyond any doubt, this is one of the main reasons for it to be preferred in Armenian and avoided in English.

If the speaker wishes to be more polite and at the same time wants to show coldness and lack of intimacy, the infinitive can be combined with a verb used in a performative way:

I ask you to give this message for God Almighty's sake.

(Dickens 1945:105).

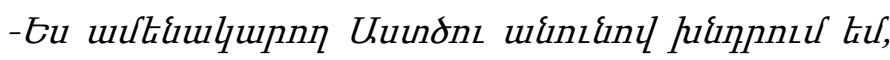
np \&puiq hujunitip hu uuuhi:

(Dickens 1988:588)

In this perspective it should be mentioned that the infinitive directive functions as a distance-building device in Armenian, similar to interrogative devices, used in English. But in Anglo-Saxon cultures distance is a positive cultural value, related to respect in order to express the individual's autonomy. Conversely, in Armenian culture distance will be associated with hostility and

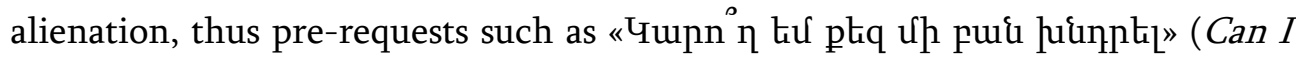

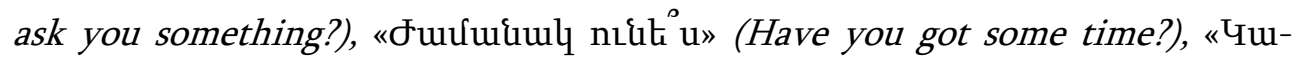
nn $\eta$ tiu hud̃ oquiti", (Can you help me?) are usually used to be more polite.

\section{Conclusion}

Thus, we can conclude that Armenians tend to show positive face since each representative of Armenian culture expects to be accepted and liked by others. As part of a collectivistic culture, Armenians like to be treated as a member of the same group and to know that their needs and desires can be 
shared by others. It is worth remembering that Armenians try to avoid conflicts and make the hearers feel good about themselves by paying much attention to their desires, needs, and interests, hence it can be claimed that positive politeness is highlighted in Armenian culture.

On the contrary, in English culture people value individuality and independence, therefore it is a vivid illustration of an individualistic culture. As is stated, individualistic cultures focus on characteristics like independence and assertiveness. They value a person's freedom to act and appreciate personal identity. Thus, in English culture, negative politeness is more stressed and people tend to show negative face, indicating the need to be independent, to keep privacy and have right to non-distraction. So, in English culture requests are made within negative politeness strategies.

\section{References:}

1. Brown, P., Levinson, S.C. (1987) Politeness: Some Universals in Language Usage. Cambridge: CUP.

2. Held, G. (1999) Submission Strategies as an Expression of the Ideology of Politeness: Reflections on the Verbalization of Social Power Relations. //“Pragmatics", 9 (1).

3. Leech, G. (1983) Principles of Pragmatics. New York: Longman.

4. Paronyan, Sh. (2012) Pragmatics. Yerevan: Asoghik.

5. Triandis, H.C. (2001) Individualism-Collectivism and Personality. USA: Blackwell Publishers.

6. Yule, G.(1996) Pragmatics. Oxford: OUP.

\section{Sources of Data:}

1. Dickens, C. (1988) Oliver Twist. Yerevan: Arevik.

2. Dickens, C. (1945) Oliver Twist. New York: Pocket Books.

3. Fitzgerald, F.S. (1941) The Last Tycoon. USA: Charles Scribner's Son.

4. Galsworthy, J. (1932) The Forsyte Saga. UK: Penguin Books.

5. Galsworthy, J. (1975) The Forsyte Saga. Yerevan: Hayastan Hratarakchutiun.

6. Galsworthy, J. (1976) The Silver Spoon. Moscow: Progress Publishers. 


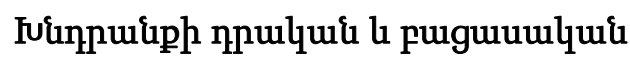 punupul|upnıpjuis nuqưulupulquis dlitpp

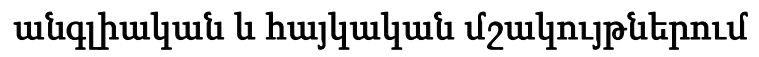

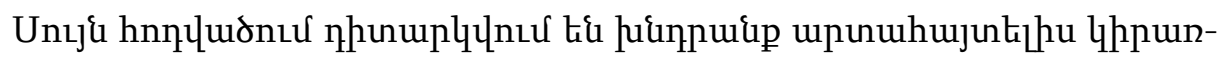

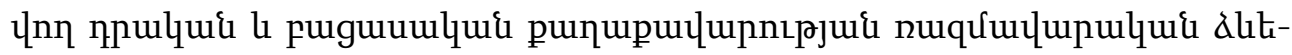

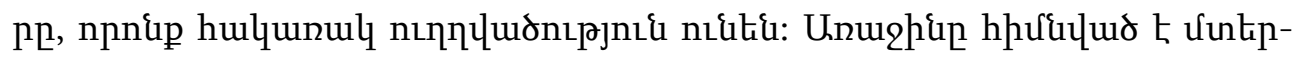

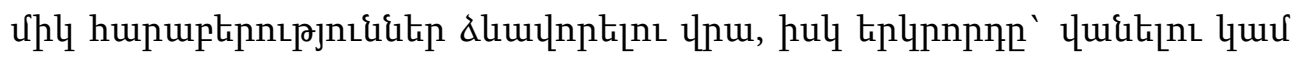

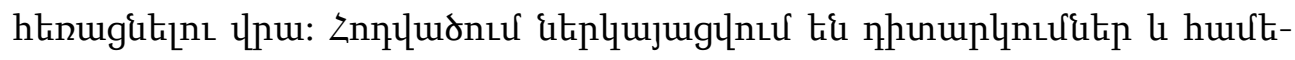

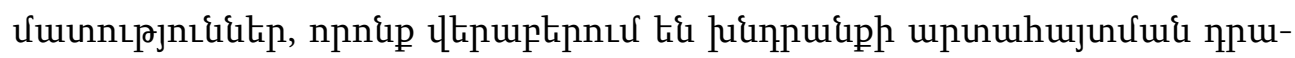

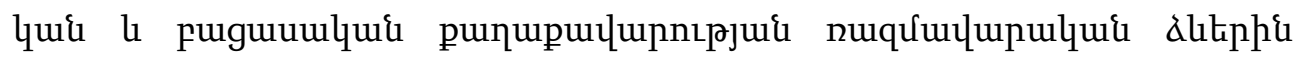

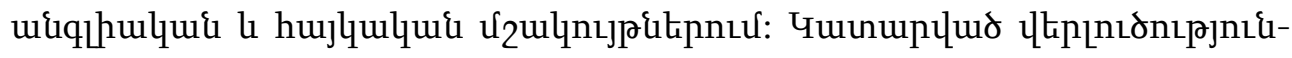

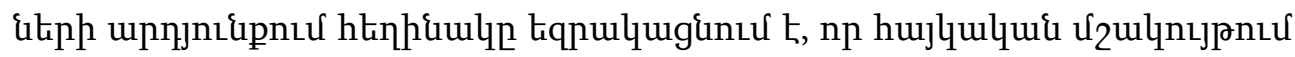

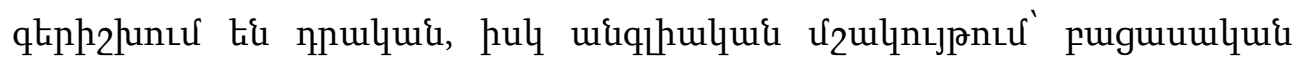

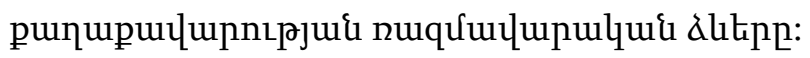

Received by the Editorial Board 26.02.2019

Recommended for publication by the reviewers 02.04.2019

Accepted for print 22.04.2019 